Email: jassp@kpa.unila.ac.id, Website: https://jassp.lppm.unila.ac.id

Volume 1, Number 2, October 2021

\title{
Smart Culture in Smart City Policies: A Case of Yogyakarta City
}

\author{
Muhammad Iqbal ${ }^{1}$ \\ ${ }^{1}$ Department of Political Science, National Cheng Kung University, Taiwan (R.O.C) \\ Correspondence: Muhammad Iqbal, National Cheng Kung University, Taiwan (R.O.C). \\ E-mail: U18097019@ncku.edu.tw \\ Received: March 26, 2021 Accepted: September 21, 2021 Online Published: October 21, 2021
}

\begin{abstract}
The concept of developing Smart Cities in Yogyakarta is different from the development of Smart Cities in other cities. The Smart City of Yogyakarta is under the big idea of Smart Culture, divided into two fields, namely Smart Education and Smart Tourism. This big concept was taken because Yogyakarta is very thick with its Culture and is known as an education city and tourism city. The idea of Smart Culture is expected to touch all aspects of the lives of the citizens of Yogyakarta that are inseparable from the six basic principles of developing Smart Cities. This study uses a quantitative approach. Data survey was conducted using a questionnaire to the civil servant in Yogyakarta City. The survey results will be analyzed using Smart PLS 3.0 software. The results of this study are divided into two components, namely Tangible and Intangible Culture. This Smart Culture's primary purpose is to make Tangible and Intangible Culture in Yogyakarta City survive and excel. Smart Culture in the city of Yogyakarta acts as an umbrella that underlies the development and other intelligent programs such as smart education and smart Culture. These two components are revealed to be critical projects that can be included in short and medium-term programs on smart education or smart tourism related to Culture. Other findings show that tangible Culture and intangible Culture have a significant influence on smart Culture development.
\end{abstract}

Keywords: Smart Culture; Smart City; Public Policy; Yogyakarta City

\section{Introduction}

The concept of a smart city or better known as a smart city is very popularly developed as a concept for structuring cities globally in recent years and the rapid development of technology ( Haitami, M., \& Rengganis, A. 2021). This concept initially grew since the 1990s, when internet connections began to go global since their introduction in the 1960s. According to (Allwinkle, S., \& Cruickshank, P. 2011) the development of the internet during that period made services easier with information that could be accessed through websites provided by the city government. Although it is still limited to a one-way service with only static and limited details on urban policies, land use, and planning, it is undeniable that this is the beginning of the emergence of the concept of a smart city ( Anggraini, A. T., \& Iqbal, M. 2020).

The stat (Nuzir, F. A., \& Saifuddin, R. 2015) that cities will be smart if investment in human resources, social capital, and infrastructure for traditional and modern communication systems can increase sustainable economic growth and quality life with a wise management of natural resources through participatory governance. Besides, Cohen ( Cohen. 2012) divides the smart city into six dimensions, namely.
a. Smart economy;
b. Smart Mobility;
c. Smart environment;
d. Smart people;
e. Smart living; and
f. Smart governance. 
Meanwhile, Djunaedi (Djunaidi, 2014) adds one more dimension related to smart cities, namely smart disaster management related to the Indonesian state's location, which is in the ring of fire. To realize Yogyakarta Smart City, the implementation of e-government in the Yogyakarta City Government has become a necessity ( Faidat, N., \& Khozin, M. 2018). The vision of the performance of information and communication technology in the Yogyakarta City Government is contained in the e-government master plan document stipulated in the Yogyakarta Mayor Regulation Number 15 of 2015 concerning e-Government, namely "The realization of eGovernment as a means of reliable management information systems for the City of Yogyakarta in supporting effective, efficient, transparent, accountable and participatory public services so that it becomes Yogyakarta Smart City" ( Iqbal, M., et al. 2020). The Yogyakarta City Development Planning Agency prepared the 20152019 Road Map for e-Government development in 2014. In the road map, there are five stages of e-Government development for the Yogyakarta City Government towards the city of Yogyakarta as a smart city, namely ( Faidat, N., \& Khozin, M. 2018) ( Faraji, S. et al. 2021):

The first stage, strengthening network infrastructure and data centers;

a. The second stage, reinforcing the information system infrastructure;

b. The third stage, data integration, and integrated application development;

c. The fourth stage, the data warehouse; and

d. The fifth stage; implementation of policies towards a smart city.

The steps have been described in the road map for e-government development ( Fanea-Ivanovici, M., \& Pana, M. C. 2020). However, specifically related to smart city, which includes seven dimensions, namely: smart economy, smart people, smart governance, smart mobility, smart environment, smart living, and smart disaster management, have not been described in more detail ( Allam, Z., \& Newman, P. 2018) (Xu, H., \& Geng, X. (2019). Along with their respective indicators/benchmarks (Voronkova, Valentina. 2017) (Voronkova, Valentyna, Kyvliuk, O. et al. 2018).

The concept of developing a Smart City in Yogyakarta is different from the development of a Smart City (Smart City) in other cities. The Smart City Yogyakarta is under the umbrella of Smart Culture, divided into two areas, namely Smart Education and Smart Tourism ( Faidat, N., \& Khozin, M. 2018). Yogyakarta City is very thick with its culture and is known as the city of education and tourism ( Neve, M. 2018). The concept of Smart Culture is expected to touch all aspects of the lives of the people of Yogyakarta, which are inseparable from the six basic principles of developing a Smart City (Pratama, \& Imawan. 2020).

The PSPPR UGM team considers the development of the Smart City concept in Yogyakarta with the Smart Culture umbrella to be sufficient following the vision of the city of Yogyakarta, namely, The realization of a City of Quality Education, Character and Inclusion, Culture-Based Tourism, and Service Center, with insight Environment and People's Economy. The PSPPR team revealed that the vision of the city of Yogyakarta had four keywords, namely tourism, education, culture, and service centers; these four keywords were then developed to become the basis for the Smart Culture concept.

\section{Method}

The research used is quantitative. Quantitative analysis in terms of objectives, this study is used to test a theory, present a fact or describe statistics, and to show the relationship between variables and those that are developing concepts, developing understanding or defining many things (Subana. 2005).This study uses a questionnaire technique and literature study to obtain data to analyze the phenomenon. The population of this study are the civil servant in Yogyakarta City. The population of this study was 5564 civil servant in Yogyakarta City. The sample of this study was calculated using the Slovin formula. The sample are 100 respondents. The results of the questionnaire were then processed using SmartPLS 3.0 software.

\section{Discussion}

\subsection{Demographic Profile of Respondents}

Table 1 shows that the number of respondents based on gender consists of $58 \%$ male respondents and $42 \%$ female respondents. Meanwhile, based on age, the respondents are predominantly by the age of 21-30 years by $32 \%$. $48 \%$ of respondents aged $31-40$ years old and $20 \%$ were more than 40 years old. Besides, most 
respondents are a Bachelor's degree, as many as $61 \%$ of respondents. Furthermore, $27 \%$ of respondents are a high school. On the other hand, $12 \%$ of respondents are graduate.

Table 1 Respondents' Demographic Profile

\begin{tabular}{ccc}
\hline Variables & Number & Percentage (\%) \\
\hline Male & 58 & 58 \\
Female & 42 & 42 \\
Age & & \\
$21-30$ years & 32 & 32 \\
31-40 years & 48 & 48 \\
$>40$ years & 20 & 20 \\
Education & & \\
Senior High School & 27 & 27 \\
Bachelor & 61 & 61 \\
Graduate & 12 & 12 \\
\hline
\end{tabular}

3.2 Validity and Reliability Analysis

The validity test result (table 2) shows that all variables, culture, health, mobility, and smart living implementation in Yogyakarta City have an Average Variance Extracted (AVE) value greater than 0.500. The AVE value is valid if the AVE score is more than 0.50 (Ghozali. 2006). Based on the criteria, all variables are declared valid. Meanwhile, the reliability test using Composite reliability and Cronbach's Alpha shows that the construct is reliable if it is above 0.70 (Ghozali. 2006). The validity test result (Table 2) shows that both composite output reliability and Cronbach alpha were above 0.70 . So each construct in the estimated model has good reliability.

Table 2 Validity and Reliability Test

\begin{tabular}{ccccc}
\hline Variables & $\begin{array}{c}\text { Cronbach } \\
\text { Alpha }\end{array}$ & Rho_A & $\begin{array}{c}\text { Composite } \\
\text { Reliability }\end{array}$ & $\begin{array}{c}\text { Average Variance Extracted } \\
\text { (AVE) }\end{array}$ \\
\hline Tangible & 0.901 & 0.903 & 0.921 & 0.816 \\
Intangible & 0.888 & 0.890 & 0.900 & 0.823 \\
Smart Culture Implementation & 0.921 & 0.918 & 0.940 & 0.913 \\
\hline
\end{tabular}

\subsection{Path coefficients testing}

The study results in Figure 1 show that smart culture implementation in Yogyakarta City is influenced by tangible and intangible variables by $\mathrm{R}^{\wedge} 2=0.483$ or $48.3 \%$. If associated with the Rule of Thumb for testing according to (Ghozali, 2016) the structural model, which has a result of 0.67 , it indicates that the model is "good", which is 0.33 , suggests that the model is "moderate." The is 0.19 , meaning that the model is "weak." So it can be concluded that the variables that affect the smart culture implementation variable have a moderate influence level.

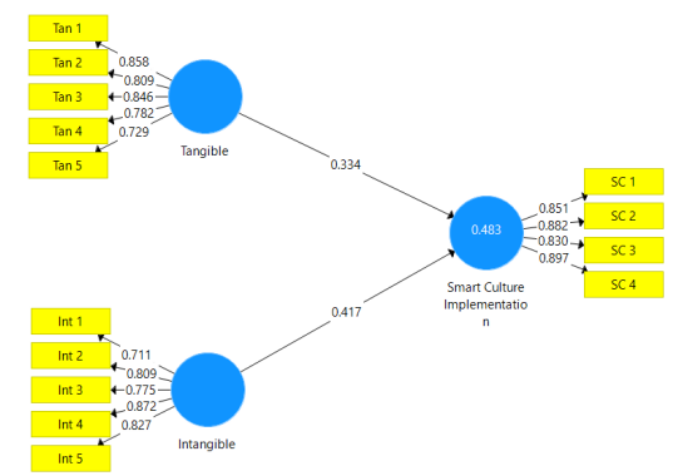

Figure 1. Outer Model in Smart Living Implementation 
Hypothesis testing between variables, namely "exogenous variables against endogenous variables $(\gamma)$ and endogenous variables against exogenous variables $(\beta)$, was carried out using the bootstrap resampling method after seeing the validity and reliability of the data. The test statistic used is the $t$ statistic or $t$-test. The comparative $t$ value in this research is obtained from the $t$ table. The test is declared significant if the statistical value T $>1.96$ and the value of the P-value $<0.05$ " (Ghozali, 2016). Path coefficients testing is done by looking at the output path coefficient of bootstrap resampling. The results are as follows:

Table 3. Path coefficients testing

\begin{tabular}{ccccccc}
\hline Variables & $\begin{array}{c}\text { Original } \\
\text { Sample }\end{array}$ & $\begin{array}{c}\text { Sample } \\
\text { Mean }\end{array}$ & $\begin{array}{c}\text { Standard } \\
\text { Deviation }\end{array}$ & $\begin{array}{c}\text { T - } \\
\text { Statistic }\end{array}$ & P-Value & State \\
\hline Tangible & 0.211 & 0.203 & 0.114 & 2.293 & 0.024 & Accepted \\
Intangible & 0.252 & 0.244 & 0.131 & 2.251 & 0.029 & Accepted \\
\hline
\end{tabular}

Based on table 4, Tangible and intangible cultures significantly influence the implementation of smart culture in Yogyakarta City. This is supported because the city of Yogyakarta has the potential for physical culture "Tangible Culture" consisting of a Cultural Heritage Area.

\section{Conclusion}

Culture by (UNESCO. 2013) is an integral part of spiritual, material, intellectual and emotional in a community or social group, including art, literature, lifestyle, ways of living together / society, systems and values, traditions, and beliefs. As a city with one of the visions as a culture-based tourism city, Yogyakarta makes Culture one of the essential things to pay attention to in achieving its city's goals.

The city of Yogyakarta has the vision to become "A City of Education-Quality, Character and Inclusion, Culture-Based Tourism, and Service Center, which has an Environmental and Community Economy Concept". This vision has 4 (four) keywords: tourism, education, Culture, and service centers. These four keywords will be developed to develop a smart city in the city of Yogyakarta, with the main umbrella being smart Culture ( Ramadhani, R., Purnomo, E. P., \& Kasiwi, A. N. 2020). If described further, smart tourism; smart education; and smart Culture are the 3 (three) main goals of Yogyakarta's smart city which can be achieved through the implementation of 7 (seven) smart service indicators, namely, smart environment, smart mobility, smart government, smart economy, smart people, smart living, and smart disaster management (Lombardi, P. et al. 2012).

Smart City Yogyakarta's primary goal can be achieved if the achievement indicators from the dimensions of smart Culture, smart tourism, and smart education are met (Surmiyatun \& Prayitna, 2020). Smart Culture has the primary achievement indicator, namely the preservation of the cultural values of Yogyakarta. The study of Smart Culture is divided into two components, namely Tangible and Intangible Culture. This Smart Culture's main objective is so that Tangible and Intangible Culture in Yogyakarta City can survive and excel. Smart Culture in Yogyakarta City acts as an umbrella that underlies the development and other smart programs such as smart education and smart Culture. These two components are derived into crucial projects that can be included in short and medium-term programs on smart education or smart tourism related to Culture.

Movable and immovable cultural heritage objects, museums, and other cultural heritage (Saujana). The Cultural Conservation Areas, which have been designated by Governor Decree 326 / KPYS / 1995 only cover 7 Cultural Heritage Areas (Kraton, Puro Pakualaman, Prambanan, Ambar Binangun, Ambar Ketawang and Parangtritis and Kotagede) while currently 13 Cultural Heritage Areas are spread out. In 4 districts and cities consisting of 6 cultural heritage area's in urban areas (Kraton, Tamansari, Puro Pakualaman, Kotabaru, Malioboro, Kotagede) 3 cultural heritage area's in suburban areas (Prambanan, Ambar Ketawang, Ambar Binangun) and 4 cultural heritage area's in Rural areas (Pratama \& Imawan, 2020).

In terms of urban planning, most of the cultural heritage objects do not have a "Buffer Space". Buffer Space, the minimum space requirement that covers cultural heritage objects, functions as a minimal viewing space on the site and spread to monitor the dangers of fire or damage by irresponsible people. Besides, there is no spatial use/layout for preservation and protection as well as space for socio-cultural activities and community tourism, 
conservation, and security of the assets of the Endangered Cultural Heritage Area, such as the Powered Area, which is the site of the Mataram kingdom (Sultan Agung) and has a significant value related to the background of the existence of the Ngayogyokarto Hadiningrat Palace.

The absence of buffer space and settlements in cultural heritage areas or sites results in land change and land grabbing. The Transfer of land and building functions and crushing/attaching to cultural heritage assets by settlements or erecting houses on cultural heritage artifacts, such as rubble-benteng Alun-Alun in Kotagede area and on Tamansari artifacts. The absence of buffer space also results in no room to secure and control oneself from the dangers of fire, collapse, and destruction. This is a contra-production condition that can destroy and eliminate the antiquity and beauty of high-value cultural heritage assets. In the next 15-25 years, there will be extinction and significant historical, scientific, educational, and social Culture assets.

Yogyakarta City has the potential for arts, language and literature, cultural and traditional values in the form of folk cultural values, folk games, traditional ceremonies and cultural systems, social systems, economic systems, religious and knowledge systems, conventional technology systems, and the environment, and intercultural relations. The potential of non-physical culture "intangible culture" Yogyakarta Special Region includes arts in various types and fine arts, dance, music, theatre, film/documentation, both modern and traditional crafts, in terms of the number of arts organizations and groups. There are 451 cultural activists in Yogyakarta City. Human resources in the field of art preservation, both modern and traditional, have almost stagnated in creativity due to a lack of appreciation and post-creation management, including the low rate of regeneration.

Besides, Yogyakarta is the center of Javanese language and literature, including language (literature parama, variety of languages, bausastra, dialect, sengkalan, etc.). It is spoken in the form (tales, japamantra, pawukon etc.) and Javanese script. Suppose it does not get good handling/management. In that case, the potential mentioned above will eventually experience a decrease in quality and quantity, such as a decrease in the number of Javanese language and language media speakers and literature. There are 130 cultural infrastructures to support artists' preservation and creativity development in various forms (stage, pavilion, showroom, performance room, village hall music studio, auditorium, studio, field).

In contrast, traditional cultural preservation centers are called villages. There are approximately 60 cultural villages in DIY Province and 22 tourist villages with physical and non-physical potential. The potential of cultural infrastructure is not yet an ideal number with the possibility of existing traditional arts and customs. In terms of quality, none of them has international minimum standards. To develop the potential mentioned above, it cannot be separated from cultural institutions' role, which is pretty numerous, namely 90 cultural institutions. The potential for cultural institutions has not yet become a network capable of organizing and managing all cultural activities in Yogyakarta.

\section{Acknowledgments}

Thank you for Department of Political Science National Cheng Kung University, Taiwan (R.O.C)

\section{References}

Allam, Z., \& Newman, P. (2018). Redefining the Smart City: Culture, Metabolism and Governance. Smart Cities, 1(1), 4-25. https://doi.org/10.3390/smartcities 1010002

Allwinkle, S., \& Cruickshank, P. (2011). Creating smart-er cities: An overview. Journal of Urban Technology, 18(2), 1-16. https://doi.org/10.1080/10630732.2011.601103

Anggraini, A. T., \& Iqbal, M. (2020). The Uttilization of Jogja Smart Service Application: an E-Readiness Approach. Journal of Governance and Public Policy, 7(2), 150-159. https://doi.org/10.18196/jgpp.72130

Faidat, N., \& Khozin, M. (2018). Analisa Strategi Pengembangan Kota Pintar (Smart City): Studi Kasus Kota Yogyakarta. JIP (Jurnal Ilmu Pemerintahan) : Kajian Ilmu Pemerintahan Dan Politik Daerah, 3(2), 171180. https://doi.org/10.24905/jip.3.2.2018.171-180

Fanea-Ivanovici, M., \& Pana, M. C. (2020). From Culture to Smart Culture. How Digital Transformations Enhance Citizens' Well-Being through Better Cultural Accessibility and Inclusion. IEEE Access, 8, 37988-38000. https://doi.org/10.1109/ACCESS.2020.2975542

Faraji, S. J., Jafari Nozar, M., \& Arash, M. (2021). The analysis of smart governance scenarios of the urban 
culture in multicultural cities based on two concepts of "cultural intelligence" and "smart governance." GeoJournal, 86(1), 357-377. https://doi.org/10.1007/s10708-019-10074-6

Haitami, M., \& Rengganis, A. (2021). The Dilemma of Good Governance Implementation in Indonesia during the Pandemic of Corona Virus Disease (COVID-19). Journal of Advance in Social Sciences and Policy, 1(1), 55-67. https://doi.org/10.23960/jassp.v1i1.25

Iqbal, M., Pribadi, U., \& Elianda, Y. (2020). Factors affecting the citizen to use e-report application in Gunungkidul Regency. Smart Cities and Regional Development Journal, 4(2), 27-39.

Lombardi, P., Giordano, S., Farouh, H., \& Yousef, W. (2012). Modelling the smart city performance. Innovation: The European Journal of Social Science Research, 25(2), 137-149. https://doi.org/10.1080/13511610.2012.660325

Neve, M. (2018). Would Urban Cultural Heritage Be Smart? Culture As a Land Factor and Italian Cities'Smartness. Journal of Communication and Languages, (48). Retrieved from http://www.fcsh.unl.pt/rcl/index.php/rcl/article/view/111

Nuzir, F. A., \& Saifuddin, R. (2015). Smart people, smart mobility. Atlantis Press, (September), 1-5. https://doi.org/10.13140/RG.2.1.3056.4324

Ramadhani, R., Purnomo, E. P., \& Kasiwi, A. N. (2020). E-Government Assessment pada Kualitias Aplikasi Jogja Smart Service (JSS) di Kota Yogyakarta. Jurnal Pemerintahan Dan Politik, 5(2), 58-62. https://doi.org/10.36982/jpg.v5i2.1031

Voronkova, Valentina. (2017). Philosophical Reflection Smart-Society as a New Model of the Information Society and its Impact on the Education of the 21 st Century. Future Human Image, 1(7), 154-162.

Voronkova, Valentyna, Kyvliuk, O., Nikitenko, V., \& Oleksenko, R. (2018). "Stem-Education" As A Factor In The Development Of "Smart- Society": Forming Of "Stem-Competence." Гуманітарний Вісник Запорізької Державної Інженерної Академії, 72, 148-162.

Xu, H., \& Geng, X. (2019). People-Centric Service Intelligence for Smart Cities. Smart Cities, 2(2), 135-152. https://doi.org/10.3390/smartcities2020010 